\begin{tabular}{|c|c|}
\hline $\begin{array}{l}\text { खसक } 6 \\
\text { JAN } 062000\end{array}$ & 1 EDT 628505 \\
\hline
\end{tabular}

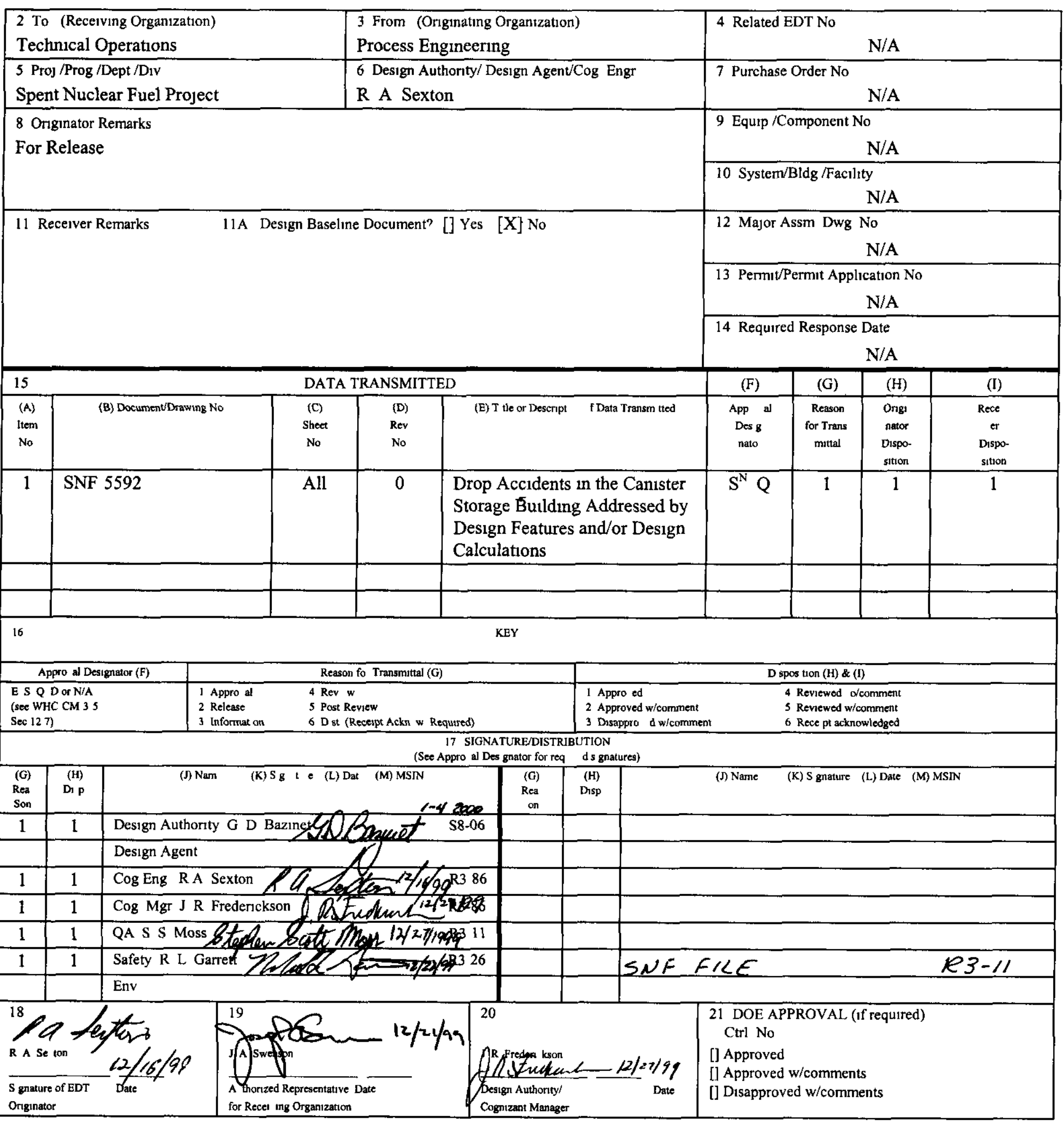

BD 74001722 (05/96) GEF097 


\title{
DROP ACCIDENTS IN THE CANISTER STORAGE BUILDING ADDRESSED BY DESIGN FEATURES AND/OR DESIGN CALCULATIONS
}

\author{
R A Sexton* \\ Fluor Daniel Hanford Richland WA 99352 \\ U S Department of Energy Contract DE AC06 96RL13200
EDT/ECN $628505 \quad$ UC 510
Org Code $87100 \quad$ Charge Code 105355/A010
B\&R Code EW7040000 Total Pages 25

Key Words Canıster Storage Buldıng Spent Nuclear Fuel Drop Accidents

Abstract A variety of drop shear or impact scenarios have been identified for the Canister Storage Bulding Some of these are being addressed by new calculations or require no specific action This document describes five of them which are addressed by design features and/or existing design calculations For each of the five a position is stated indicating the reason for assurance that the safety functions of the MCO will not be jeopardized by the accident Following the position is a description of the basis for that position

Technical Resources International Inc Richland Washington

\footnotetext{
TRADEMARK DISCLAIMER Reference herein to any specific commercial product process or service by trade name trademark manufacturer or otherwise does not necessarily constitute or imply its endorsement recommendation or favonng by the United States Government or any agency thereof or its contractors or subcontractors
}

Printed in the United States of America To obtain copies of this document contact Document Control Services P O Box 950 Malstop H6 08 Richland WA 99352 Phone (509) 3722420 Fax (509) 3764989
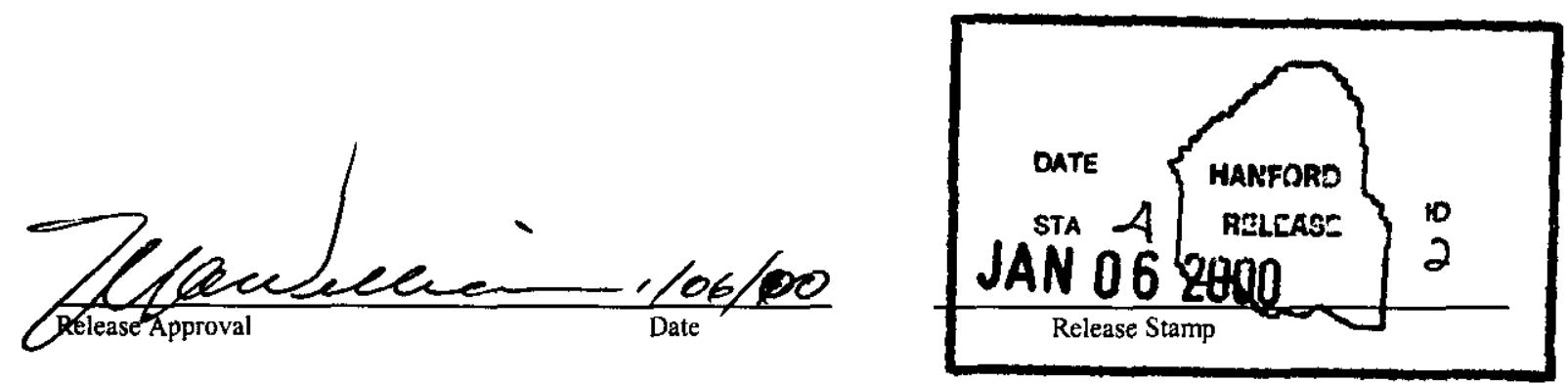

\section{Approved for Public Release}


Drop Accidents in the Canister Storage Building Addressed by Design Features and/or Design Calculations

TABLE OF CONTENTS

10 INTRODUCTION 2

20 CASK DROP INTO CASK RECEIVING PIT 3

30 DROP CASK LID ONTO MCO 4

40 MHM FALL ONTO OPERATING DECK RESULTING IN MAJOR STRUCTURAL DAMAGE TO DECK

50 DROP MCO ONTO IMPACT ABSORBER IN STORAGE TUBE OR WELD/SAMPLE STATION

60 DROP MCO ONTO ANOTHER MCO IN STORAGE TUBE (NO INTERMEDIATE IMPACT ABSORBER)

70 REFERENCES $\quad 8$

\section{APPENDIX}

A Table 2-1 Mult1-Canıster Overpack Process Steps and Possible Drop Shear, or Impact Scenanos 


\section{INTRODUCTION}

A total of 36 possible drop, shear, or impact scenanos have been identified for the Canister Storage Bulding They are summarized in a table in Appendix A Some of these are being addressed by new calculations or require no specific action This document describes five of them, which are addressed by design features and/or existing design calculations For each of the five, a position is stated, indicating the reason for assurance that the safety functions of the MCO will not be jeopardized by the accident Following the position is a description of the basis for that position

In the heading of each section, a number in parenthesis following the title corresponds to the number of the scenario in Appendix A 


\section{CASK - MCO DROP INTO CASK RECEIVING PIT (7)}

Position - The impact absorber in the cask receiving pit will limit deceleration forces in the MCO to $35 \mathrm{~g}$ The MCO and its internals were designed to withstand this deceleration

Basıs - 1) CSB Impact Absorber Analysis Report, ED-037, Rev 0, by PacTec of Tacoma, Washington, (Noss, 1999) demonstrates the design requirements have been met The document states, "The primary design requirement for the CSB impact absorber designs is to not exert a force in excess of $34 \mathrm{~g}$ (35g for the MCO Service Station application) For the IMP-4, the gross weight of the MCO Transportation Cask 15 59,000 pounds which results in a force limit of 2,065,000 pounds corresponding to the $35 \mathrm{~g} \mathrm{limit}$, The impact absorber for the cask recelving pit is designed for a drop height of $2342 \mathrm{ft}$ (281 in ) The maximum height of the cask receiving pit impact absorber is 45 in The impact absorber design was developed by a combination of calculations and both static and dynamic tests

2) Full scale prototypic tests of the designed impact absorber were performed and are documented in Test Report for the CSB Prototypic Impact Absorbers, TR-003, Rev 0, by PacTec of Tacoma, Washington (Clark, 1999) The test uses video records to demonstrate an acceptable deceleration While a direct crush measurement of the impact absorber indicates a deceleration load that is higher than expected and higher than the design criteria, this is attributed to energy transferred to the ground upon impact The video record is regarded as the more reliable method of demonstrating that the design critena have been met

3) The Mult -Cantster Overpack Design Report, HNF SD-SNF-DR 003, Rev 2 DE\&S Hanford Richland, Washington, (Smith, 1999) demonstrates that the MCO will meet design criteria Appendix 7 contains the design calculation that shows that the Mark 1A internals can withstand design basis conditions of a $35 \mathrm{~g}$ vertical drop or a $101 \mathrm{~g}$ horizontal drop These criteria are to preclude criticality in the Mark 1A fuel with a flooded MCO and do not apply to the Mark IV internals Table 7 of the appendix summanzes analysis of 12 components of the Mark 1A baskets, all with predicted maximum loads below allowable values 


\section{DROP CASK LID ONTO MCO (12)}

Position - A drop of the cask lid onto the MCO would cause only local cosmetic damage at the point of impact, but the $\mathrm{MCO}$ would maintain its containment and confinement functions

Basis - Multt-Cansster Overpack Analysis File Documentation, Appendix B Cask Lid Accidental Drops Onto Mult-Canister Overpack HNF-SD-SNF-DP-007, Rev 0, DE\&S Hanford, Richland, Washington, (Chenault, 1997) evaluated cask lid drops In this analysis the critical hd onentation, when the hd center of gravity is vertically above the first point of contact, was used for three different impact positions The three impact positions were to the lifting ring, the shield plug at the location of one of the cover plates, and the MCO outer cylinder along side the lifting ring

The analysis concludes that the MCO maintains containment and confinement of all Spent Nuclear Fuels during and after a $5 \mathrm{ft}$ drop of a cask lid The local plastic damage would only be found by close inspection of the hardware after the event 


\section{MHM FALL ONTO OPERATING DECK, RESULTING IN MAJOR STRUCTURAL DAMAGE TO DECK (19)}

Position - The MHM is designed for seismic loads and will not fall onto the operating deck

Basis - The MHM design includes seismic features that preclude it from falling in a seismic event These are described in Multicanister Overpack Handling Machine (MHM) 100\% Design Report, (Foster Wheeler, 1998)

The trolley is provided with lateral seismic restraints in the " $\mathrm{X}$ direction Two trolley seismic locks are provided to hold the trolley during seismic motions in the East-West direction The restraints consist of pins that engage with pockets in steel pads welded to the top surface of each bridge beam

The trolley is restrained in the $Y$ " and "Z" directions with passive systems that do not require deployment

The trolley is restrained in the Y" direction by the wheel flanges The trolley is restrained in the " $Z$ ' direction by four lugs which hook beneath the top flange of the girders

The bridge is restrained in the ' $\mathrm{Y}$ ' direction by rall clamps that are spring applied and hydraulically removed Passive restraints are in place in the $X$ and $Z$ "directions It is restrained in the X" direction by wheel flanges and in the Z" direction by shaped hooks which reach under the rail head to prevent vertical uplift

A seismic shutdown contactor is mounted in the CSB such that in a seismic event the main incoming power to the MHM is disconnected, thereby, putting the MHM into its 'safe shutdown' state

Seismic analysis of the MHM was performed and is documented in Hanford MHM Seismic Analysis of the Hanford MCO Handling Machine ESL/R(96)083, Rev 3, Alstom Automation Ltd Leicester England (Cluskey, 1998) The document concludes that no gross structural fallure, overturning, or derailment will occur and no breach of containment results from the Safe Shutdown Earthquake This document does not address the unrestrained case, which will be addressed by a separate calculation 


\section{DROP MCO ONTO IMPACT ABSORBER IN STORAGE TUBE OR WELD/SAMPLE STATION (29)}

Position - The impact absorber in the storage tube or weld/sample station will limit deceleration forces in the MCO to $35 \mathrm{~g}$ The MCO and its internals were designed to withstand this deceleration

Basis - 1) CSB Impact Absorber Analysis Report, ED-037, Rev 0, by PacTec of Tacoma, Washington (Noss, 1999) demonstrates the design requirements have been met The document states, "The primary design requirement for the CSB impact absorber designs 1s to not exert a force in excess of $34 \mathrm{~g}$ ( $35 \mathrm{~g}$ for the MCO Service Station application ) The lower impact absorber for the storage tube is designed for a drop height of $4433 \mathrm{ft}$ (532 in ) The maximum combined height of the two storage tube impact absorbers is 60 in The weld/sample station impact absorber is designed for a drop height of $2025 \mathrm{ft}$ (243 in) The height of the weld/sample station impact absorber is 18 in The impact absorber designs were developed by a combination of calculations and both static and dynamic tests

2) Full scale prototypic tests of the designed impact absorbers were performed and are documented in Test Report for the CSB Prototypic Impact Absorbers, TR-003, Rev 0, by PacTec of Tacoma Washington (Clark, 1999) The test uses video records and direct crush measurements to demonstrate acceptable decelerations

3) The Mult-Canister Overpack Destgn Report, HNF-SD SNF-DR-003, Rev 2, DE\&S Hanford, Richland Washington (Smith 1999) demonstrates that the MCO will meet design criteria Appendix 7 contains the design calculation that shows that the Mark 1A internals can withstand design basis conditions of a $35 \mathrm{~g}$ vertical drop or a $101 \mathrm{~g}$ horizontal drop These criteria are to preclude criticality in the Mark 1A fuel with a flooded MCO and do not apply to the Mark IV internals Table 7 of the appendix summarizes analysis of 12 components of the Mark 1A baskets, all with predicted maximum loads below allowable values

4) Design Calculation for the MCO Sampling Statıon - Shield Components, Calculation Number CSB-RM-0016, Fluor Daniel, Inc , (Keller 1998) demonstrates that the breakaway ring is designed to break free in a MCO drop accident, but not during normal operation The MCO is supported, during normal operation so that it does not rest on the impact absorber However the breakaway ring allows the impact absorber to absorb the load during a drop accident 


\section{DROP MCO ONTO ANOTHER MCO IN STORAGE TUBE (NO INTERMEDIATE IMPACT ABSORBER) (31)}

Position - A drop of an MCO onto another MCO already loaded into the storage tube would cause plastic deformation to the bottom of the dropped $\mathrm{MCO}$ and the top of the impacted MCO shield plug but the containment and confinement functions of the MCO are not jeapordized The deceleration associated with such a drop would not damage the MCO internals

Basıs - Multi-Canister Overpack Analysis File Documentation Appendix D MultiCanister Overpack to Mult-Cantster Overpack Drop Analysis HNF-SD-SNF-DP-007, Rev 0, DE\&S Hanford, Richland, Washington, (Chenault, 1997) documents the simulation of a $31 \mathrm{ft}$ drop of a loaded MCO onto another MCO There is an impact absorber under the lower MCO, but no intermediate impact absorber between them

The analysis indicates that plastic deformation of the impacted MCO shield plug seal and shoulder would be a maximum of 0030 inches

The impact absorber under the bottom MCO would be compressed 6 to 9 inches 


\section{REFERENCES}

Chenault, D M , 1997, Multt-Canister Overpack Analysis File Documentatton, HNFSD-SNF-DP-007, Rev 0, DE\&S Hanford, Ruchland, Washington Appendix B Cask Lid Accldental Drops Onto Multt-Cantster Overpack Appendix D Multi-Canister Overpack to Mult-Canister Overpack Drop Analysis

Clark, G L , 1999, Test Report for the CSB Prototypic Impact Absorbers, TR-003, Rev 0 , PacTec, Tacoma, Washington

Cluskey, D R, 1998 Hanford MHM Selsmic Analysis of the Hanford MCO Handling Machine, ESL/R(96)083, Rev 3, Alstom Automation Ltd Leicester, England

Foster Wheeler, 1998 Multicanister Overpack Handling Machine (MHM) 100\% Design Report, Foster Wheeler Environmental Corporation

Keller, C 1998 Design Calculatıon for the MCO Sampling Station-Shield Components, Calculation Number CSB-RM-0016 Fluor Daniel, Inc

Noss, P W , 1999, CSB Impact Absorber Analysis Report, ED-037 Rev 1, PacTec, Tacoma, Washington

Smith, K E 1999 Multt-Cantster Overpack Design Report, HNF-SD-SNF-DR-003, Rev 2, DE\&S Hanford Richland, Washington 


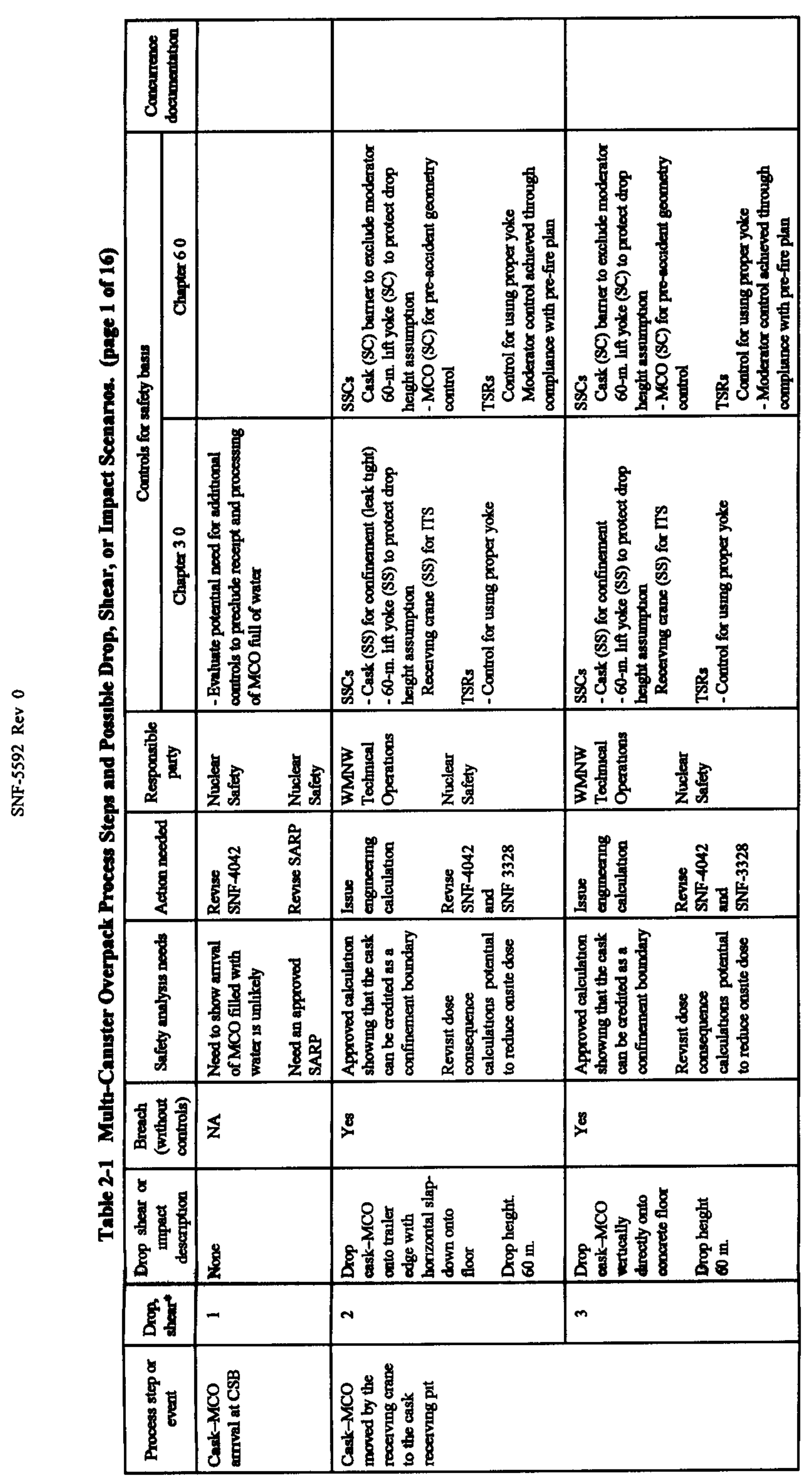




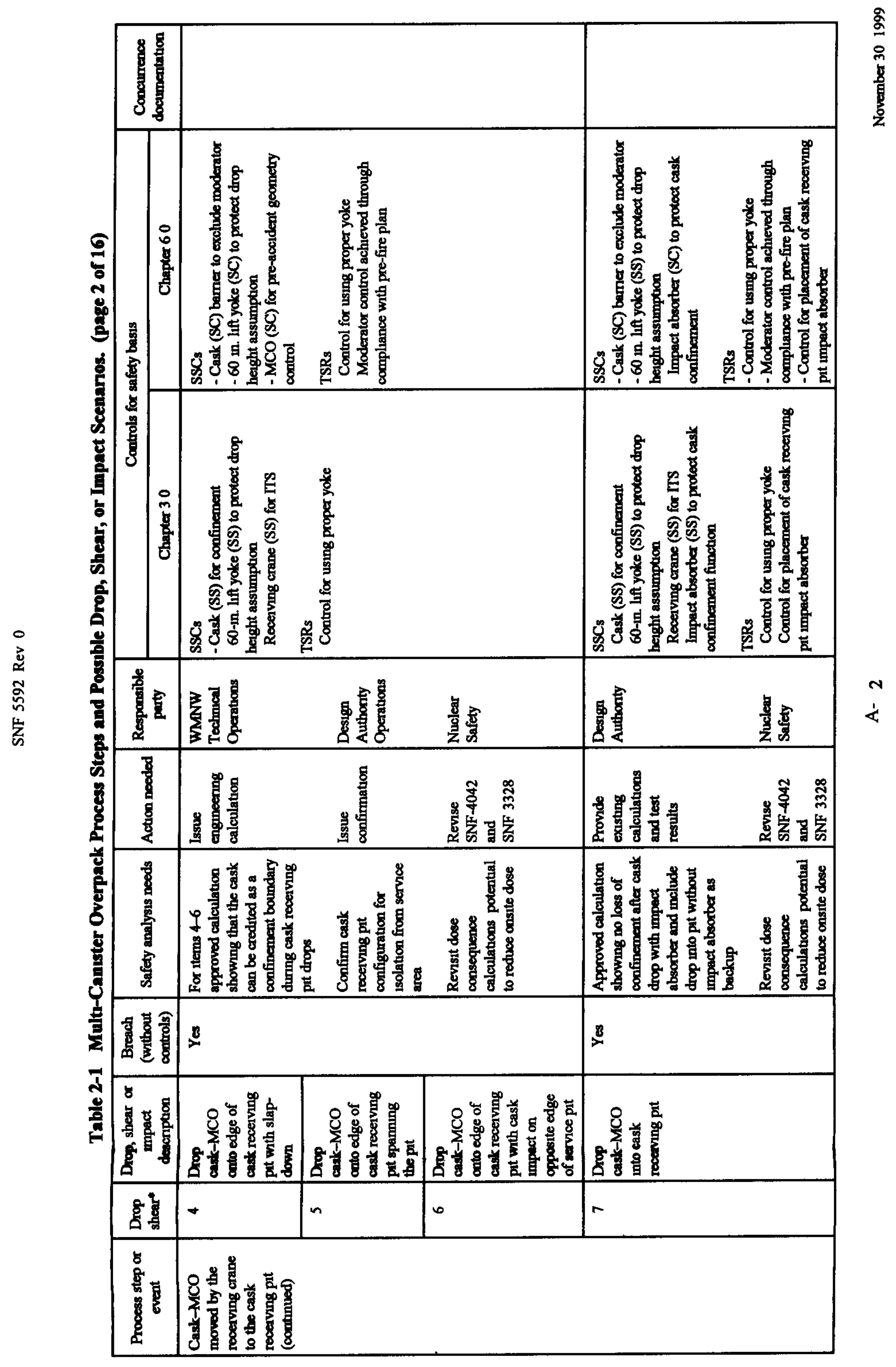




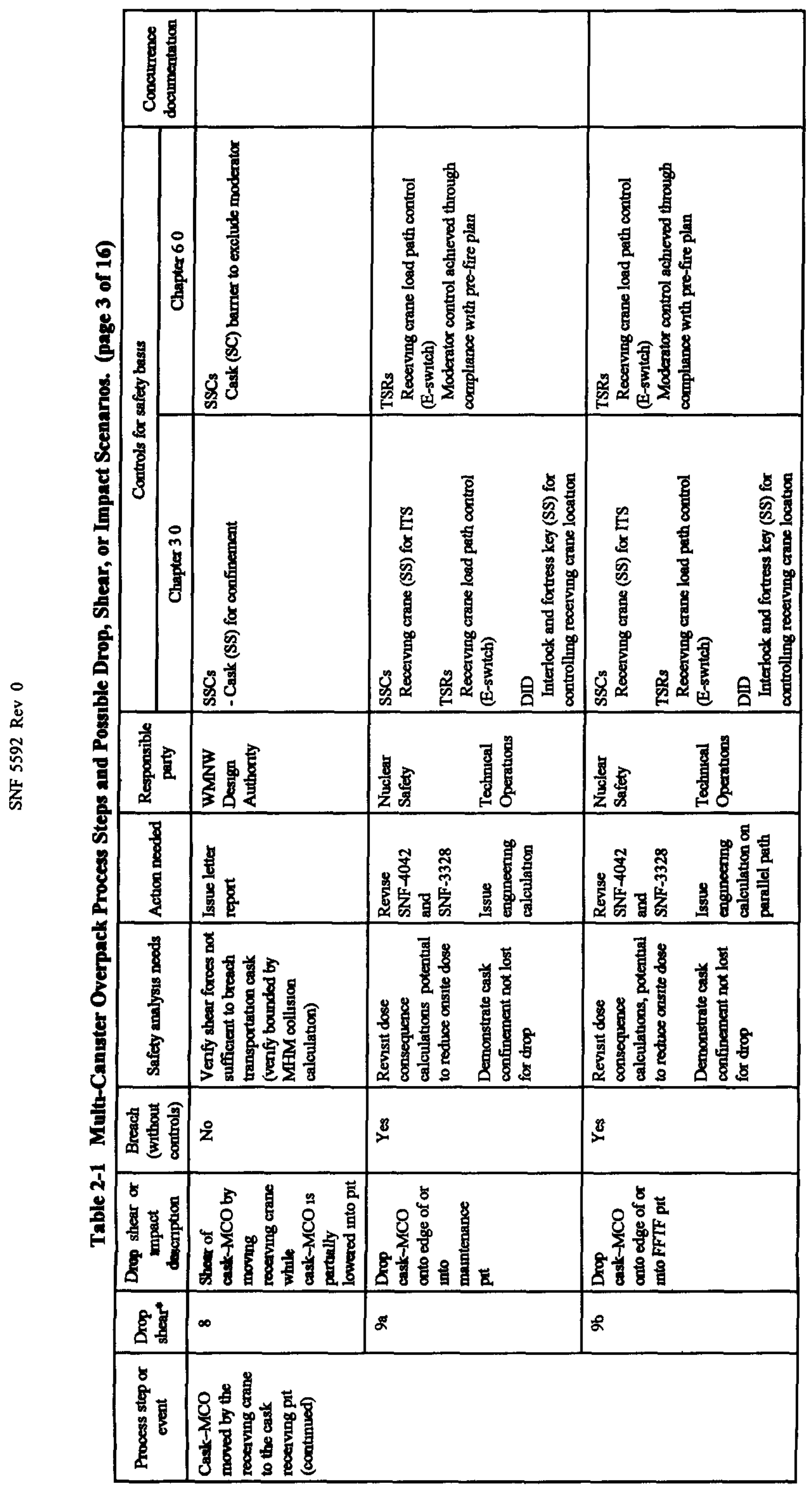




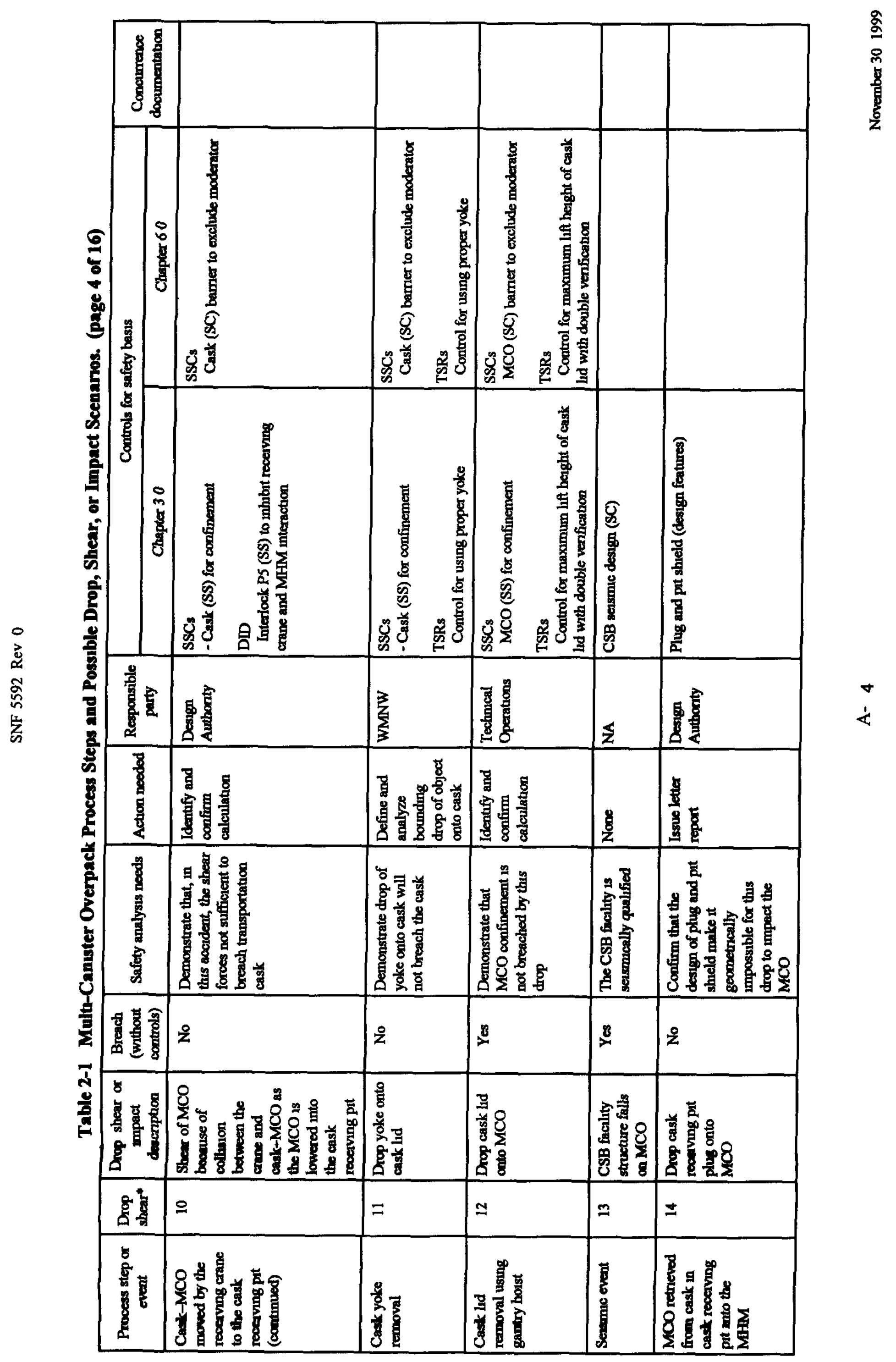




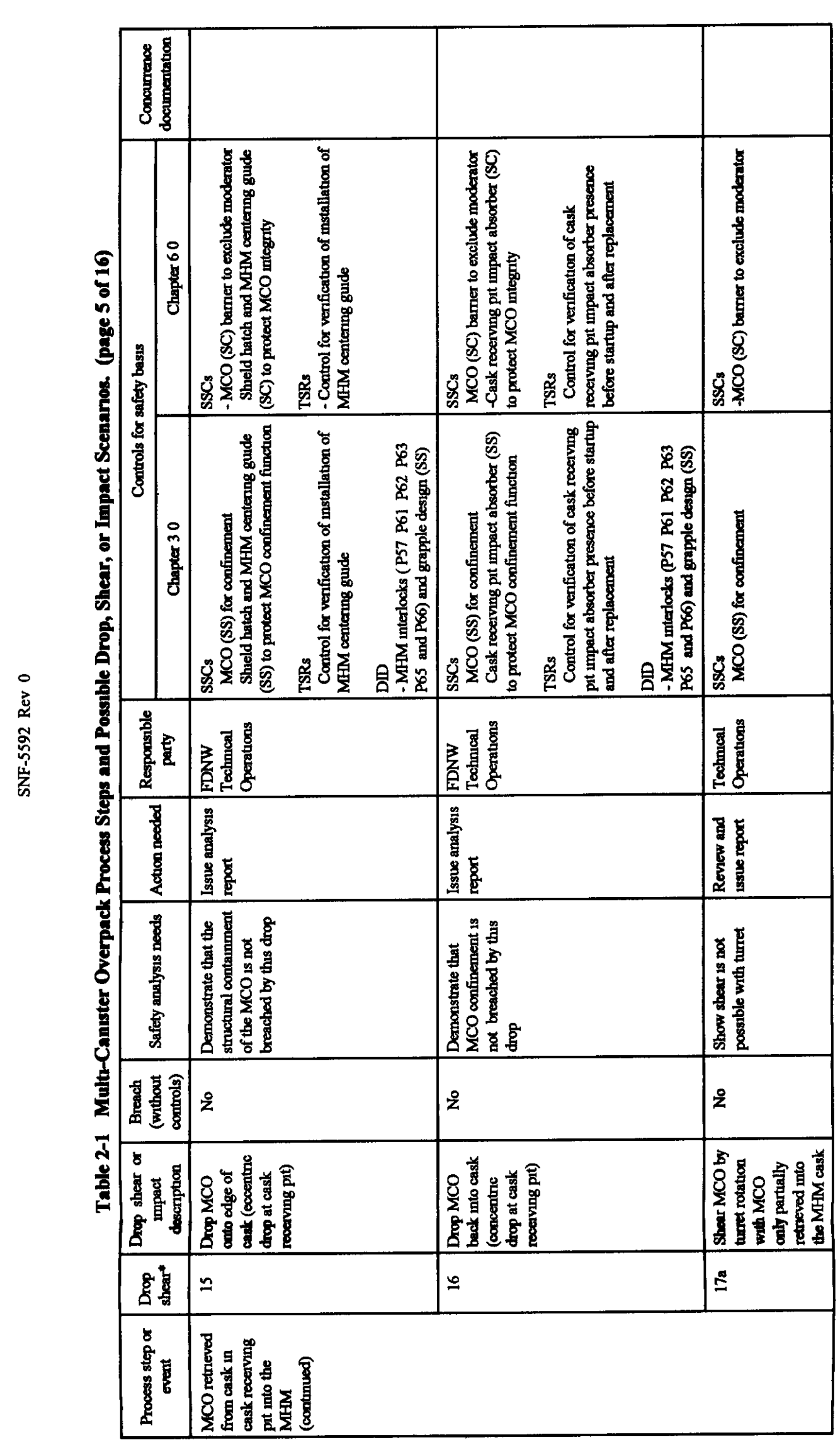

$\frac{2}{2}$ 


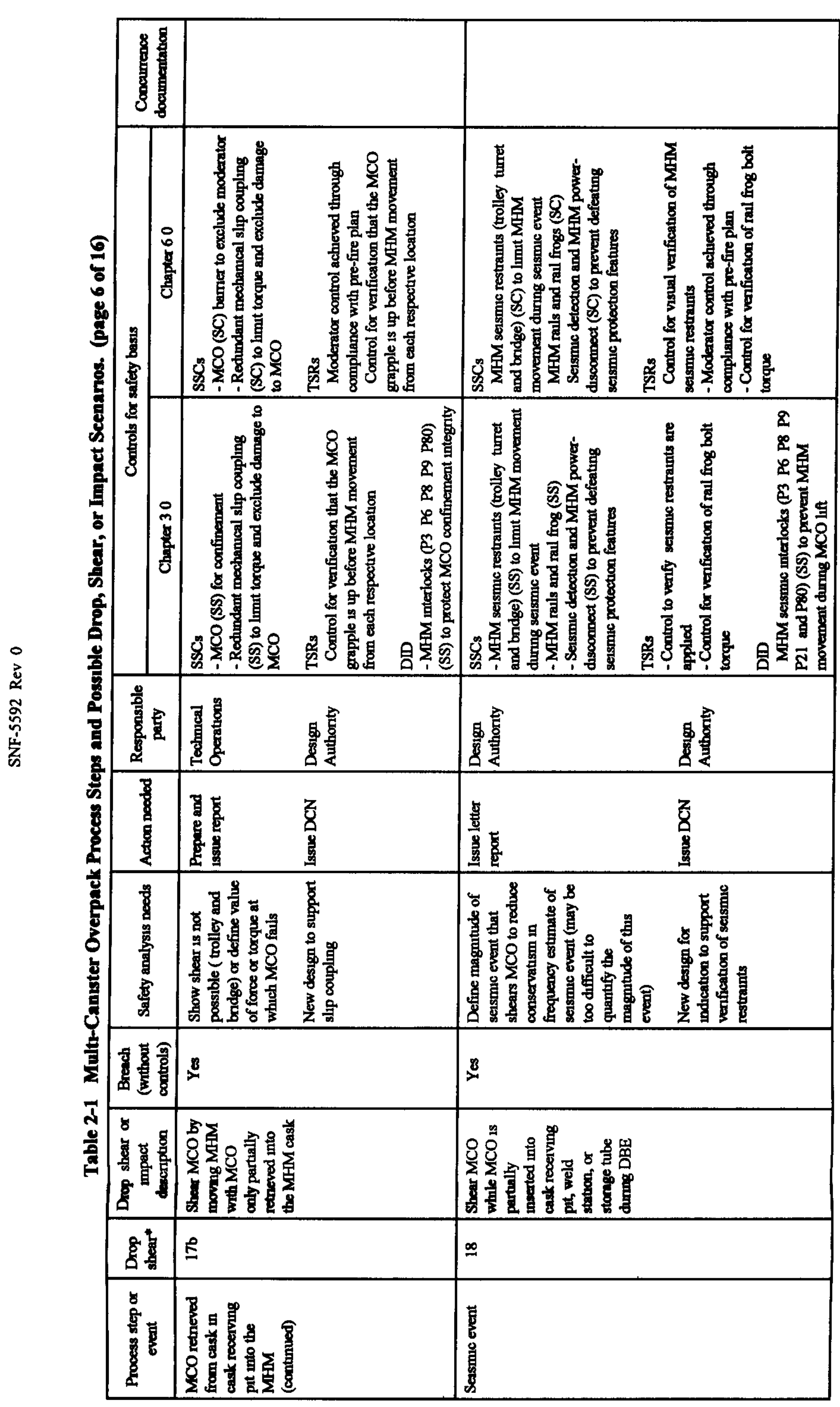




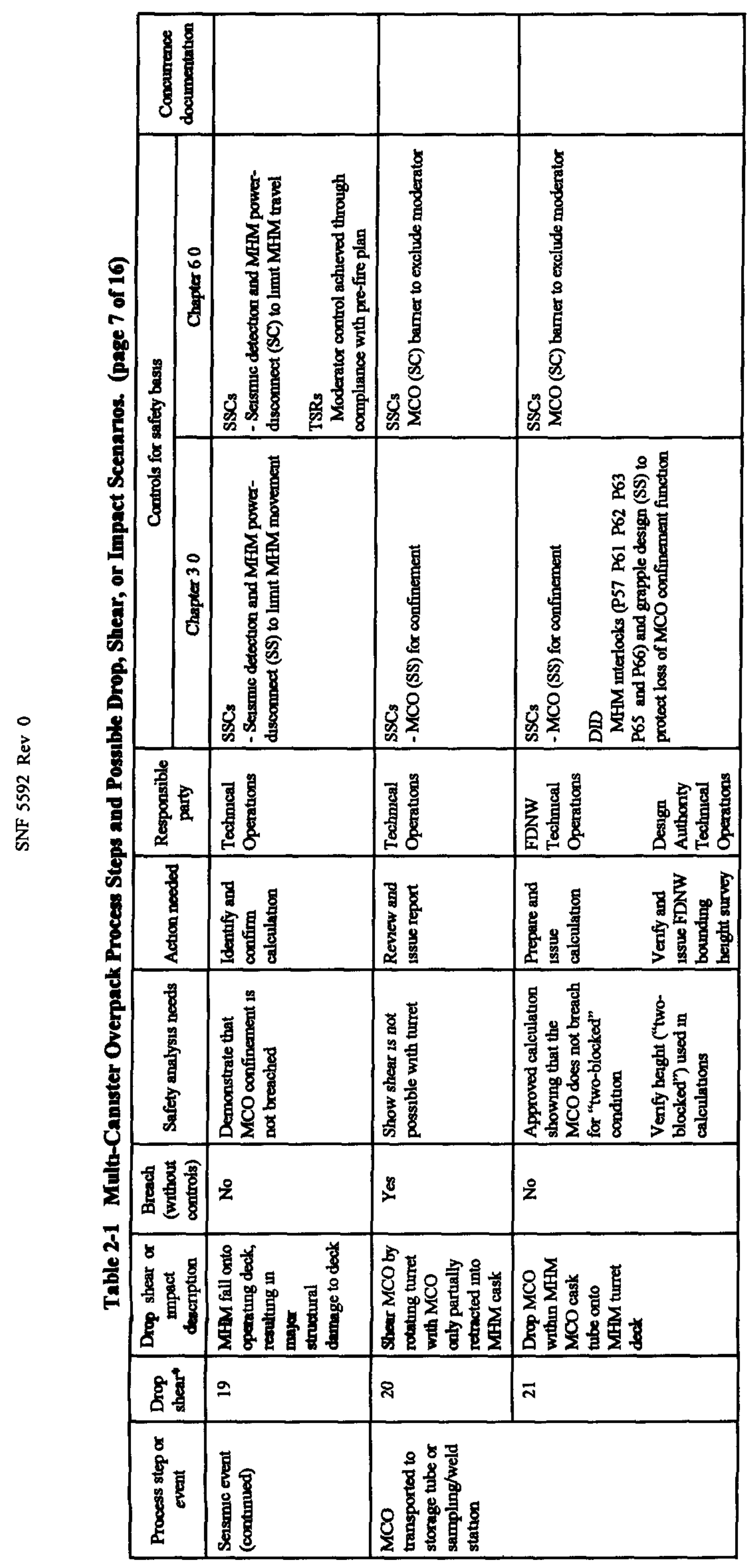

各 


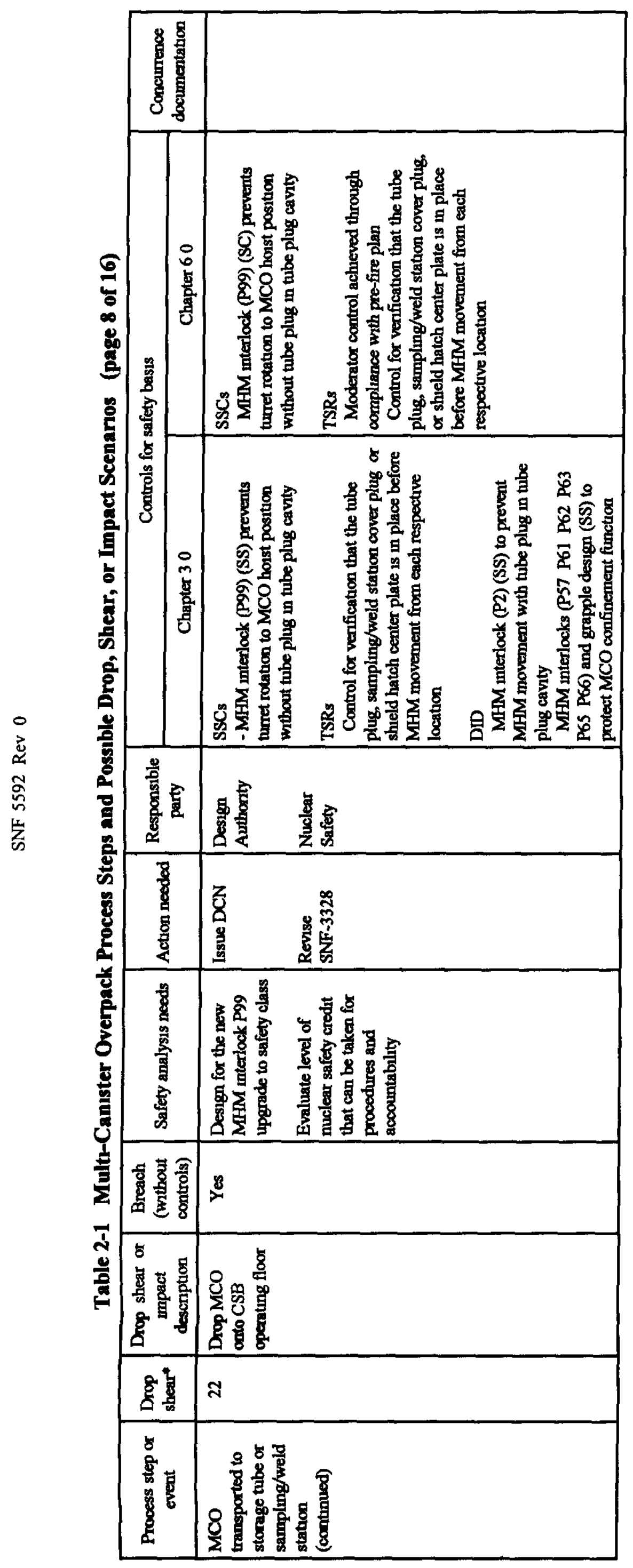




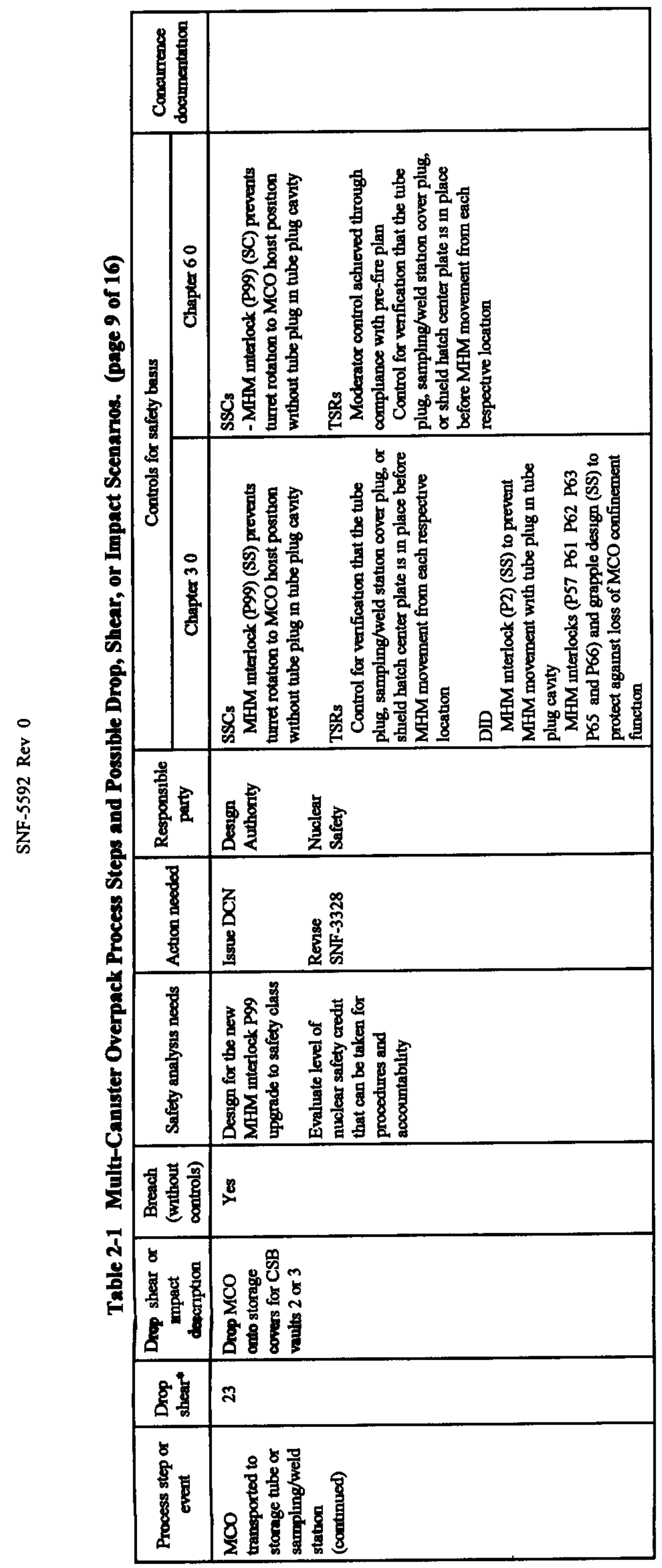

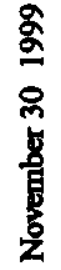




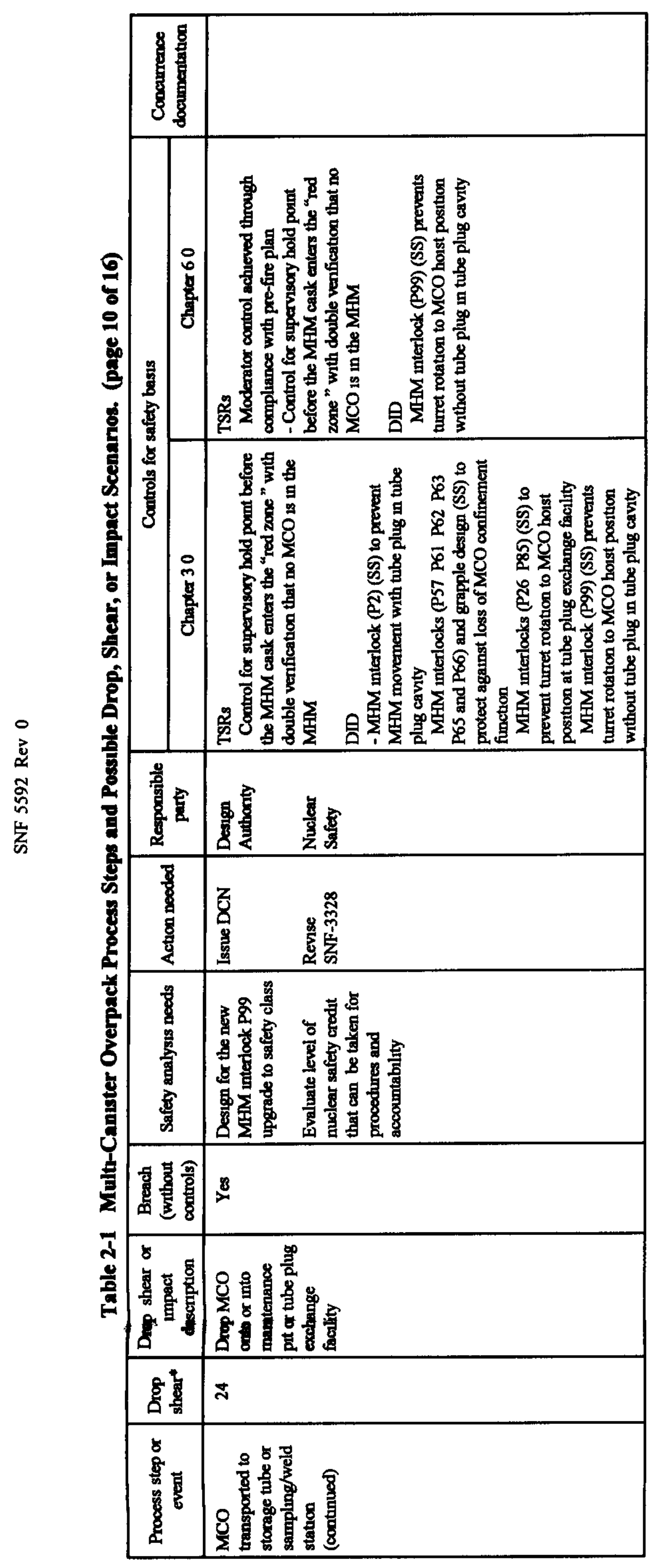

g
0
8
5
$\frac{8}{2}$

$\frac{0}{4}$ 


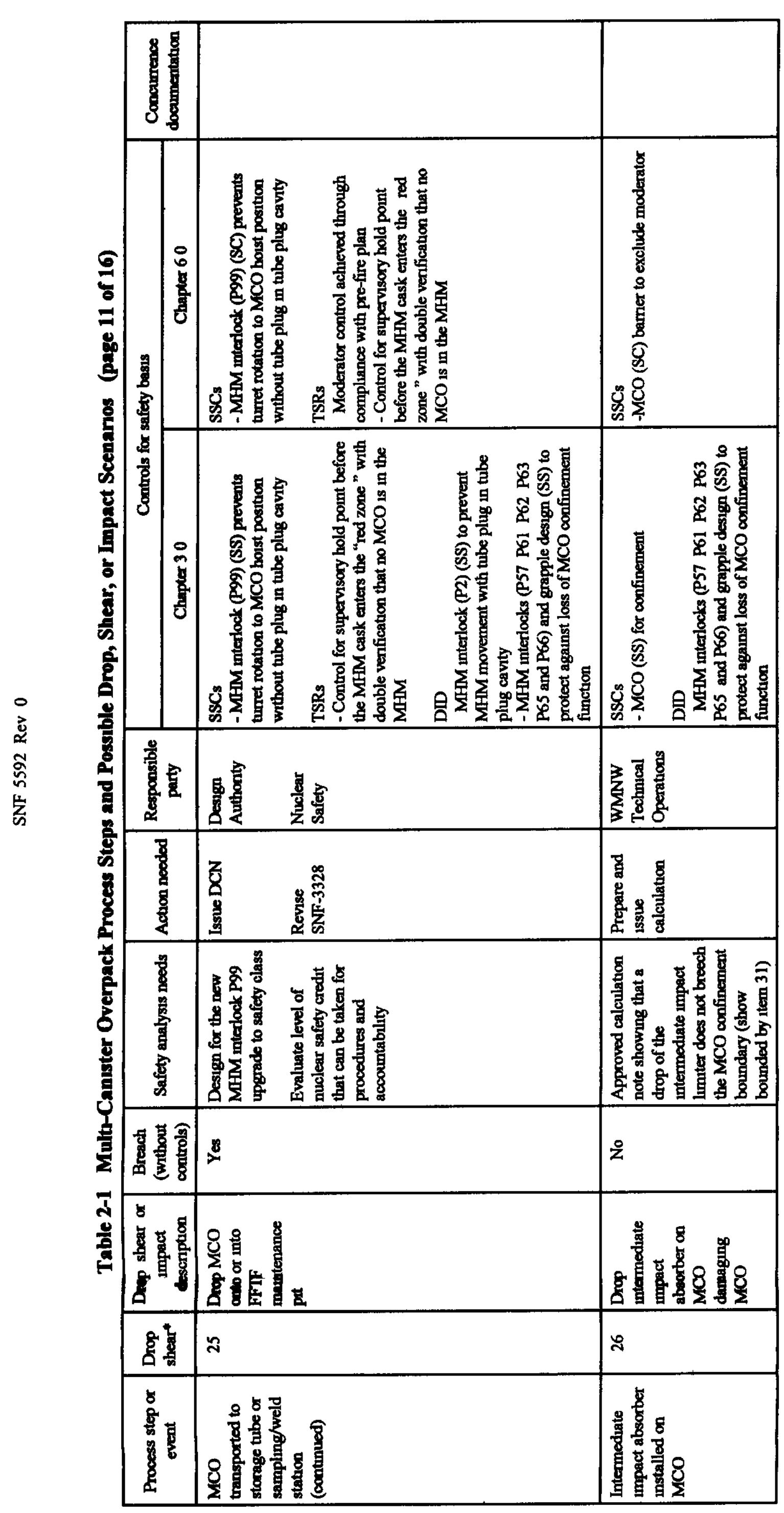

3
0
0
0
0 


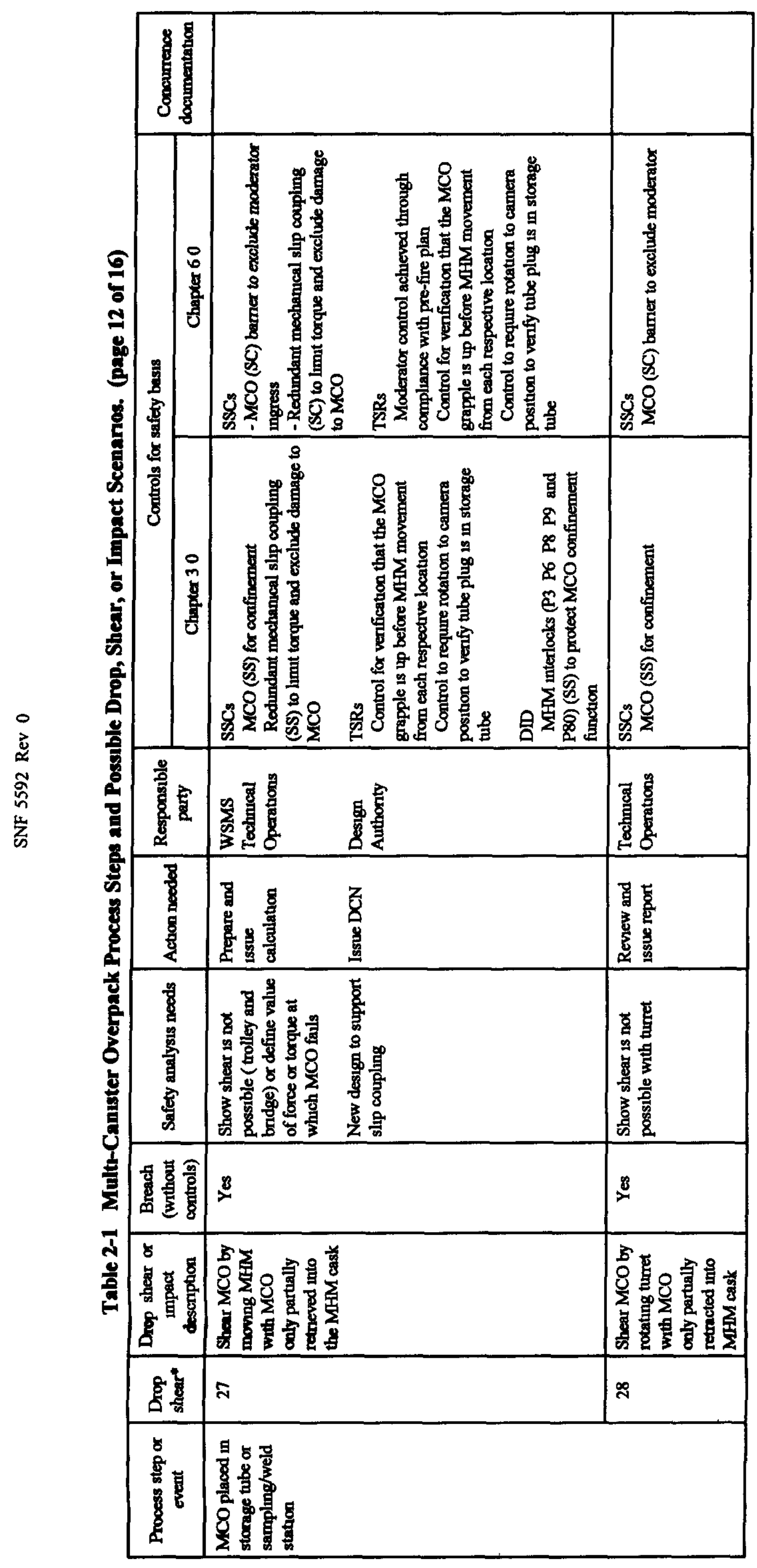




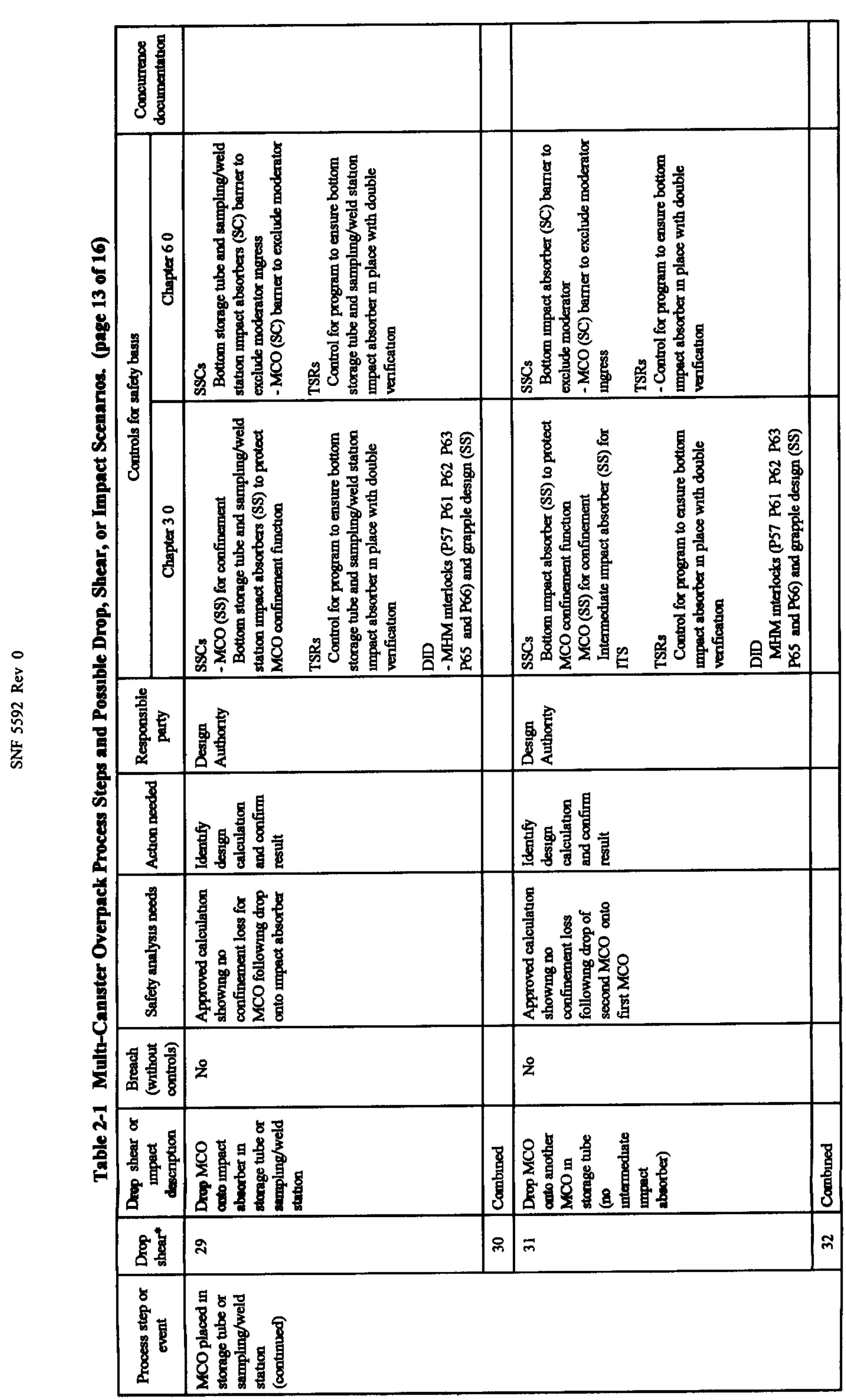




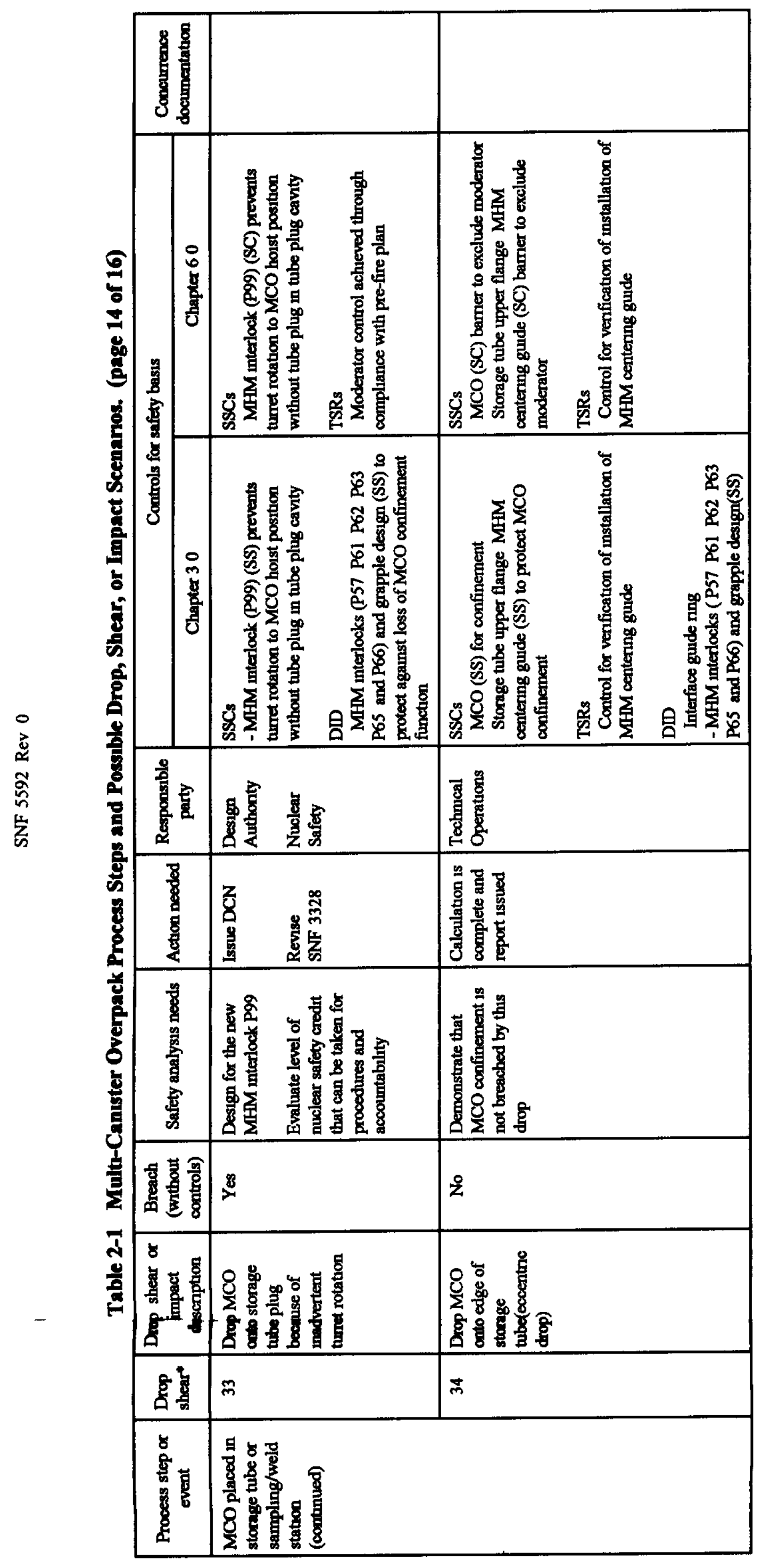

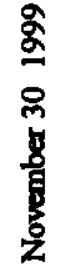

$\frac{ \pm}{4}$ 


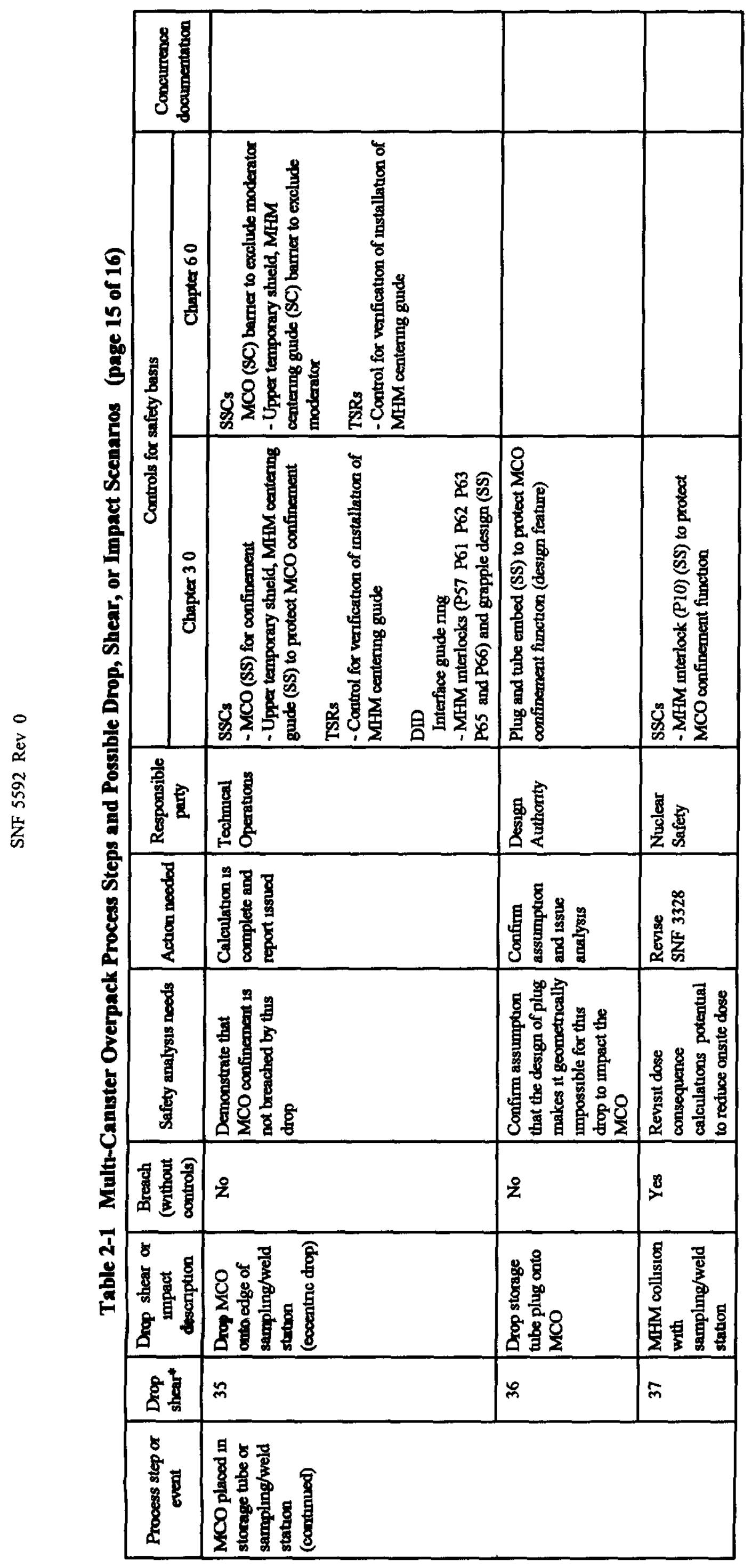




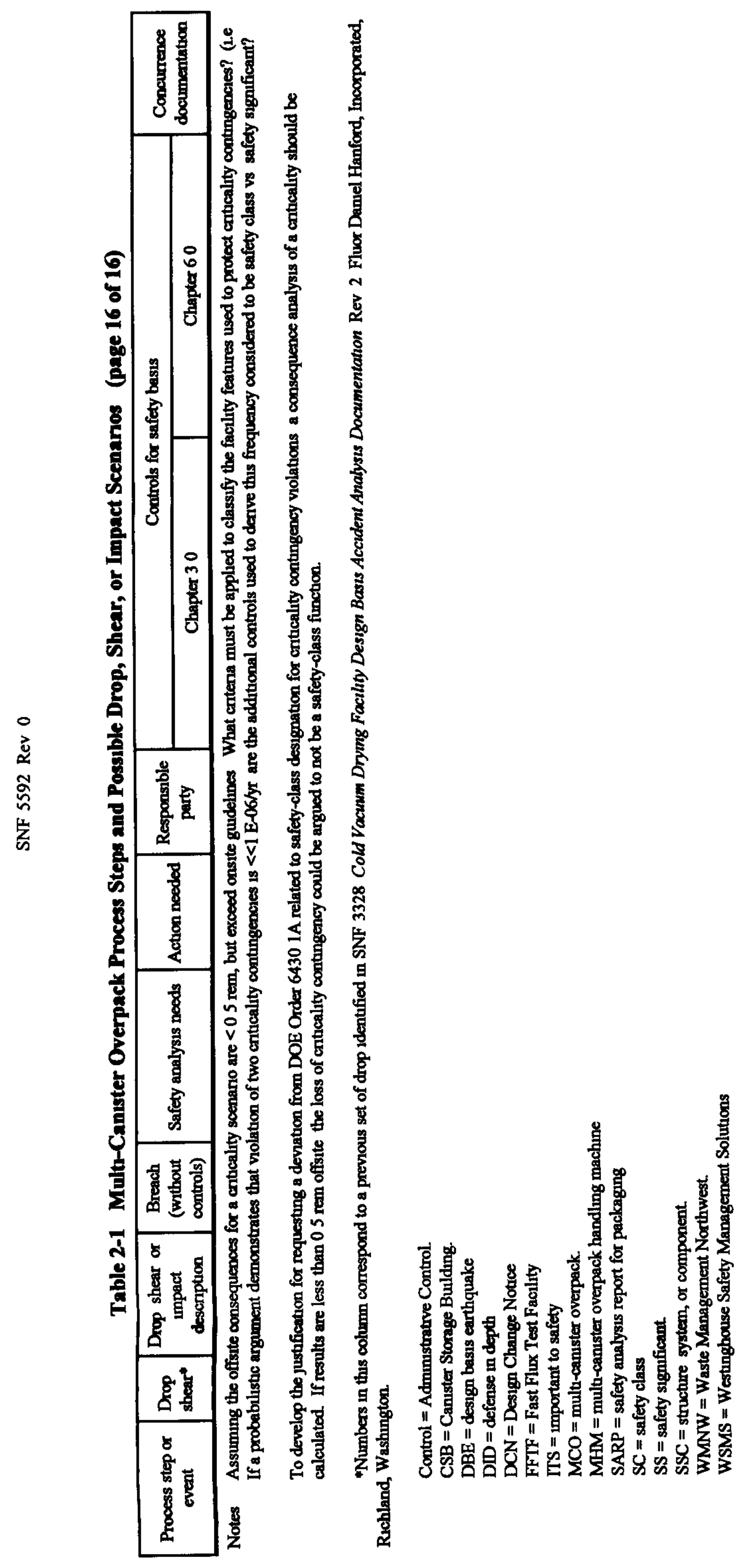

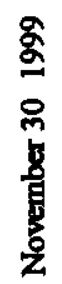

$\stackrel{1}{4}$ 